Vol. 8(4), pp. 204-213, April 2014

DOI: $10.5897 / A J$ PS2013.1020

Artic le Number: CE48CDD44223

ISSN 1996-0824

Copyright (c) 2014

African Journal of Plant Science

Author(s) retain the copyright of this a ricle

http://www.academic joumals.org/AJPS

\title{
Sustainability of maize-wheat cropping system by different legume intercropping and nitrogen level treatments on light distribution, soil temperature and crop productivity
}

\author{
R. K. Naresh ${ }^{1 *}$, S. S. Tomar ${ }^{1}$, U. P. Shahi ${ }^{2}$, S. P. Singh ${ }^{2}$, Purushottam ${ }^{3}$, B. Singh ${ }^{4}$ and \\ Parvinder Kumar ${ }^{5}$
}

${ }^{1}$ Department of Agronomy, Sardar Vallabhbhai Patel University of Agriculture and Technology, Meerut (U.P), India.

${ }^{2}$ Department of Soil Science, Sardar Vallabhbhai Patel University of Agriculture and Technology, Meerut (U.P), India.

${ }^{3}$ Department of Pathology \& Microbiology, Sardar Vallabhbhai Patel University of Agriculture and Technology, Meerut (U.P), India.

${ }^{4}$ Department of Horticulture, Sardar Vallabhbhai Patel University of Agriculture and Technology, Meerut (U.P), India.

${ }^{5}$ Department of Agricultural Meterology C. C. S. H. A. U., Hissar, Haryana, India

Received 17 February, 2013; Accepted 15 April, 2014

\begin{abstract}
Agriculture designs for cropping system with legume intercropping for increased resource use efficiency, profitability, productivity and reduced adverse environmental impact are urgently required. A three-year field experiment consisting of six cropping treatments applied during both seasons was conducted during 2008-2009 to 2010-2011 to study the effect of nitrogen and legume intercropping with maize for sustainability of maize-wheat cropping systems. Results indicate that the photosynthetic active radiation was at noon reaching nearly $1940 \mu \mathrm{mol} \mathrm{m} \mathrm{m}^{-2} \mathrm{~s}^{-1}$ for maize and $1620 \mu \mathrm{mol} \mathrm{m}^{-2} \mathrm{~s}^{-1}$ for intercropped legumes. Intercropping can increase light interception, shading and reduce evaporation as compared to sole maize. Maize intercropped had higher values of stomatal conductance and leaf temperature than pure crop. The grain yield and yield attributing characters of wheat crop increased significantly under intercropping treatments when compared with wheat only. Wheat yield significantly increased up to $160 \mathrm{~kg} \mathrm{~N} \mathrm{ha}^{-1}$. However, there was no significant increase in yield of maize beyond 120 $\mathrm{kg} \mathrm{N} \mathrm{ha}^{-1}$. Sole maize-wheat rotation showed a decline in soil organic carbon by $3.7 \%$, while black gram and cowpea intercropping with maize in paired rows (2:2 row ratio) followed by wheat had increased contents of per cent organic carbon in soil as 0.63 and 0.67 , respectively, as compared to initial values of $\mathbf{0 . 5 4 \%}$. Plots treated with intercrops/farm yard manure (FYM) during the rainy season sustained the wheat yield while the control plot showed a decline in wheat yield by $4-9 \%$.
\end{abstract}

Key words: Sustainability, intercropping, soil temperature, crop productivity.

\section{INTRODUCTION}

Traditionally, soil fertility was maintained through the application of farmyard manure. Manure was largely produced from weeds, crop residue and fodder trees that were fed to tethered animals. Currently, farmyard manure 
is the primary source of nutrients for maize fields, although the use of fertilizers is growing in importance. Since farmers apply all the manure available on their farms, it is the increased use of fertilizer that is likely to enable increases in maize production in the future. The agricultural scientists has identified chemical fertilizer as major contributing factor to accelerating agricultural growth and has considered it as one of the priority inputs. Fertilizer application per unit area in maize cultivation is lower than in other crops for two reasons. First, most of the maize is produced in the rainy season where transportation of fertilizer is costly. Second, most of the farmers are subsistent, who often do not have cash to buy expensive fertilizer. Multiple cropping (intercropping or mixed cropping) plays an important role in agriculture because of the effective utilization of resources, significantly enhancing crop productivity when compared with monoculture crops (Li et al., 1999). Introduction of a grain legume in cereal-based cropping system aims at increased productivity and profitability to achieve food and nutritional security and sustainability (Swaminathan, 1998). Intercropping is widely accepted as a sustainable practice due to its yield advantage, high utilization efficiency of light and water, pest and disease suppression (Willey, 1979; Zhu et al., 2000). According to Saleem et al. (2011) and Solanki et al. (2011), the intercropping system provides higher cash return to smallholder farmers than growing the monocrops. Most studies on intercropping have focused on resource utilization, including water light (Shackle and Hall, 1984; Donald, 1985) and nutrients (Dhiman et al., 2007), resulting in substantial yield advantage when compared with sole cropping. In the intercrop, the degree of resource complementarily, the total yield and the relative yield between the individual species is determined by both inter- and intra-specific competition, which again is influenced by the availability of environmental resources, the relative frequency of the species and the density of components (Hauggaard et al., 2006). However, the intercropped species might utilize the growth resources more efficiently than sole crops, and resources may thus support a greater number of plants. A number of mechanisms exist by which intercrops utilize resources such as light, water and nutrients more efficiently than the equivalent sole crops (Anil et al., 1998; Ghanbari et al., 2010; Undie et al., 2012).

Human efforts to produce ever-greater amounts of food leave their mark on our environment. Persistent use of conventional farming practices based on extensive tillage, and especially when combined with in situ burning of crop residues, have magnified soil erosion losses and the soil resource base has been steadily degraded (Montgomery, 2007). Now, people understand that agriculture should not only be about high yield, but also sustainable (Naresh et al., 2011). Farmers concerned about the environmental sustainability of their crop production systems combined with ever-increasing production costs have begun to adopt and adapt improved management practices which lead to the ultimate vision of sustainable conservation agriculture. Conservation agriculture addresses a concept of the complete agricultural system, combining three basic principles: (1) reduction in tillage, (2) retention of adequate levels of crop residues and cover of soil surface and (3) use of economically viable crop rotations. These conservation agriculture principles are applicable to a wide range of crop production systems. Obviously, specific and compatible management components will need to be identified through adaptive research with active farmers' involvement in contrasting agro-climatic production systems. The objective of this study was to identify the effect of nitrogen addition and different legume intercropping with maize for sustainability of maize-wheat cropping systems.

\section{MATERIALS AND METHODS}

An experiment was conducted for maize-wheat system with legume intercropping in farmers participatory mode in the jurisdiction of Sardar Vallabhbhai Patel University of Agriculture and Technology, Meerut (Uttar Pradesh), India, during 2008-09 to 201011.Treatments included: Sole maize $(60 \mathrm{~cm})$ and wheat control grown with FYM @ 10 t/ha, maize intercropped with blackgram/cowpea in paired rows $(30 / 90 \mathrm{~cm})$ in $2: 2$ row ratio, normal planted maize $(60 \mathrm{~cm})$ intercropped in 1:1 row ratio with pigeon pea/blackgram with pure stand of maize as checked under irrigated condition followed by wheat during rabi season with three nitrogen levels $(80,120$ and $160 \mathrm{~kg} \mathrm{~N} / \mathrm{ha}$ ), applied to maize as well as to wheat. The climate of the area is semi-arid, with an average annual rainfall of $805 \mathrm{~mm}(75-80 \%$ of which is received during July to September), minimum temperature of $4^{\circ} \mathrm{C}$ in January, maximum temperature of 41 to $45^{\circ} \mathrm{C}$ in June, and relative humidity of 67 to $83 \%$ throughout the year. In general, the soils of the experimental sites was sandy loam soil texture with medium fertility ( 86.5 sand, 9.2 silt and $4.3 \%$ clay) with $\mathrm{pH} 7.4$ and had $0.54 \%$ organic carbon at the time of initiation of the study. Maize and intercrop were sown simultaneously during the $1^{\text {st }}$ fourth night of June in each of the three years. Intercropping treatments were randomly allocated to main plots and $\mathrm{N}$ levels to subplots to evaluate treatments in split plot design. Nitrogen as per treatment and a uniform dose of $\mathrm{P}_{2} \mathrm{O}_{5}$ @ $60 \mathrm{~kg} \mathrm{ha}^{-1}$ to all the treatments were applied through urea and single super phosphate, respectively. 1/3 nitrogen along with full dose of phosphorus was applied as basal while remaining nitrogen was equally top-dressed at knee high and tesseling stages. During rabi season wheat crop was sown during the $2^{\text {nd }}$ fourth night of November in each of the three years.

At maturity, seed and stover/straw samples were analyzed for total $\mathrm{N}$ to determine the $\mathrm{N}$ uptake. After completion of three sequences, soil samples were analyzed for total $\mathrm{N}$ to calculate $\mathrm{N}$ fixation and $\mathrm{N}$ balance. Contribution of atmospheric nitrogen

${ }^{*}$ Corresponding author. E-mail: r.knaresh@yahoo.com.

Author(s) agree that this article remain permanently open access under the terms of the Creative Commons Attribution License 4.0 International License 
through legumes was computed by monitoring the changes in total nitrogen as well as that removed by the crop sequences by using the equation:

$\mathrm{NF}=\mathrm{NR}-\mathrm{NA}+\mathrm{N} /$ number of leguminous crops

Where, NF = Nitrogen fixed by legume crop $(\mathrm{kg} / \mathrm{ha}), \mathrm{N}=$ change in total $\mathrm{N}+$ addition depletion of $\mathrm{N}$ in soil $(\mathrm{kg} / \mathrm{ha}), \mathrm{NR}=$ total $\mathrm{N}$ removed by sequence $(\mathrm{kg} / \mathrm{ha}), \mathrm{NA}=$ total $\mathrm{N}$ applied through fertilizer or manure $(\mathrm{kg} / \mathrm{ha})$.

Soil moisture dynamics were measured at $0-20 \mathrm{~cm}$ of soil depth during the study in all treatments; using TDR probes (three replications per treatment). The measurement system for the TDR was based on a cable tester (Tektronix 1502C) coupled to a handheld computer (Husky FS/2) (Thomsen, 1994). Soil moisture content during the growing period was calculated for all treatments. The soil layer above thermometers was used to record soil temperatures. The thermometers were buried in the soil horizontally (at $20 \mathrm{~cm}$ depth), between two plants in each of the maize and intercrop rows in a middle row. The measurement of temperature in the afternoon was made on relatively clear days.

The fraction of PAR intercepted was calculated by taking ten readings in rapid succession above the canopy and ten readings below the canopy at the soil surface using a Ceptometer. The soil surface measurements were taken by placing the Ceptometer at right angles to the plant rows. Stomatal conductance and leaf transpiration were measured with a portable photosynthesis system (LI-6400 Licor, USA). Measurements were made on the flag leaf for maize and on the central mature leaflet for legume crops.

\section{RESULTS AND DISCUSSION}

\section{Photosynthetic active radiation (PAR)}

A characteristic pattern of light interception was found for each cropping systems. There was significant difference in light interception between the maize pure stands as compared to the legume intercrop. In light interception by the maize-wheat monoculture increased linearly, reaching about $80 \%$ interception for light above ground and for soil moisture is less than in many other intercropping systems. The study showed that maizewheat intercropping systems had significantly higher energy gain (more radiation intercepted) than pure crop systems. Lower PAR values were observed in Figure 1 in intercropped legumes indicating significant interception by maize leaves during the morning because of planting techniques. The greatest variation between systems occurred at 10 and $16 \mathrm{~h}$ when about 960 and $610 \mu \mathrm{mol}$ $\mathrm{m}^{-2} \mathrm{~s}^{-1}$ were intercepted. The highest values were recorded at noon reaching nearly $1940 \mu \mathrm{mol} \mathrm{m}^{-2} \mathrm{~s}^{-1}$ for maize and $1620 \mu \mathrm{mol} \mathrm{m} \mathrm{m}^{-2} \mathrm{~s}^{-1}$ for intercropped legumes. However, decreases of $1^{\circ} \mathrm{C}$ in canopy temperature in inter-cropped canopy between 8 and $10 \mathrm{~h}$ was observed. The highest canopy temperature and vapour pressure deficit (VPD) were recorded in maize in the afternoon showing high transpiration conditions during the experimentation. Maize stomatal conductance and leaf transpiration in Figure 2 were also positively affected by intercropping. Between 12 and $16 \mathrm{~h}$ values recorded were significantly higher for maize intercropping than for sole crop and highest differences were computed at $14 \mathrm{~h}$ when stomatal conductance and leaf transpiration of intercropped were $0.218 \mathrm{~mol} \mathrm{~m}^{-2} \mathrm{~s}^{-1}$ and $7.09 \mathrm{~m} \mathrm{~mol} \mathrm{~m}^{-2}$ $\mathrm{s}^{-1}$, respectively. In the sole system, these variables reached $0.110 \mathrm{~mol} \mathrm{~m}^{-2} \mathrm{~s}^{-1}$ and $5.17 \mathrm{~m} \mathrm{~mol} \mathrm{~m}^{-2} \mathrm{~s}^{-1}$, respectively.

\section{Soil moisture content (SM)}

Soil moisture content was reduced dramatically in the sole crop of maize due to high evapotranspiration potential; on the contrary, soil moisture content was increased dramatically in the legume intercropping due to low evapotranspiration potential for the growth period (Figure 3). However, comparing maize SM and legume intercropping, the patterns of soil water distribution in the soil profiles differed supporting the null hypothesis. Legume intercropping provided better soil cover as compared to sole maize, so water evaporation at soil surface was low and soil moisture was high as compared to sole maize. Distribution of root systems among species and cropping system influenced the soil moisture down the soil profile. Comparing the soil moisture content of the soil layer, the maize + cowpea intercropping tended to display the lowest differences followed by maize + pigeonpea and the highest difference followed by maize + blackgram, showing intermediate and greater differences (Figure 4). The measured soil moisture contents in the sole maize system were lower than those in the intercropping systems. In intercropping system, water uptake from soil surface layers increased due to increased root density in the upper layers, thus decreasing water dissipated by evaporation. A similar result was reported by Ghanbari et al. (2010).

\section{Growth and yield parameters}

Various inter-cropping treatments did vary significantly the growth parameters of maze, namely plant height and dry mater accumulation at 90 days after sowing (DAS) (gm/plant). These parameters also vary significantly with successive increase in nitrogen levels from $80-160 \mathrm{~kg}$ $\mathrm{N} / \mathrm{ha}$. Mean data for plant height (Table 1) reveals that plant height increased by 8.2 and $14.1 \%$ at 80 and 160 $\mathrm{kg} \mathrm{N} / \mathrm{ha}$ respectively, measured under lowest level of nitrogen (80 kg N/ha). During the three years, dry matter produced at 90 DAS was maximum at $160 \mathrm{~kg} \mathrm{~N} / \mathrm{ha}$ but remained at par with that accumulated at the preceding level of $120 \mathrm{~kg} \mathrm{~N} / \mathrm{ha}$. Mean data for dry mater accumulation at 90 DAS indicated that dry matter increased by 14.7 and $17.6 \%$ at 120 and $160 \mathrm{~kg} \mathrm{~N} / \mathrm{ha}$, respectively over the least dry matter of $102.4 \mathrm{gm} /$ plant obtained under $80 \mathrm{~kg} \mathrm{~N} / \mathrm{ha}$ (Table 1).

Intercropping treatments during rainy season had significant variations in spikelets per spike in succeeding wheat crop. Spikelets per spike obtained in the plot 

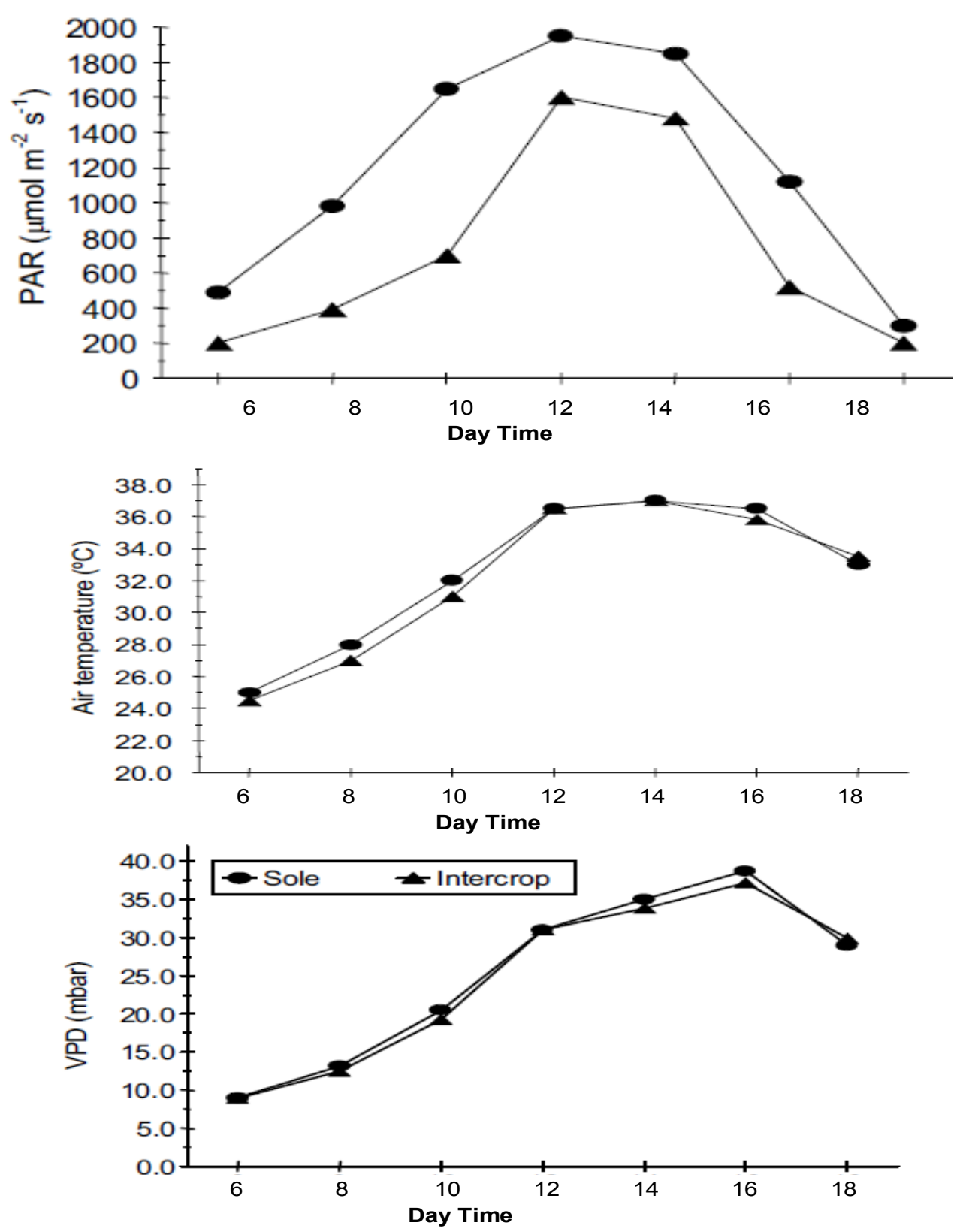

Figure 1. Diurnal fluctuation of photosynthetic active radiations (PAR), air temperature $(T)$ and vapour pressure deficit (VPD) in maize and legumes intercropped.

treated either with FYM or intercrops were significantly superior to that in control plots during respective years (Table 2). Mean data for spikelets per spike calculated for three years indicated that maximum spikelets per spike of 16.4 were counted in the treatment when the crop was raised in the plot where maize + cowpea intercropping was completed, resulting in increase tillers by $3.48 \%$ as compared to the control plot (11.8 spikelets/spike). During the three years, increasing levels of nitrogen significantly increased the spikelets per spike till up to $120 \mathrm{~kg} \mathrm{~N} / \mathrm{ha}$. Mean data for spikelets per spike (Table 2) revealed that they increased by 13.8 and $19.4 \%$ at 120 and $160 \mathrm{~N} / \mathrm{ha}$, respectively, over the least spikelets (12.5 per spike) counted at $80 \mathrm{~kg}$ nitrogen level. Shelling percent of maize remained unaffected due to different intercropping treatments in all the three years (Table 2). However, the shelling percent of maize significantly improved with increasing levels of nitrogen during the three years of the study. Mean data for shelling percent (Table 1) revealed that it was improved by 2.20 and 2.60 at 120 and $160 \mathrm{~kg} \mathrm{~N} / \mathrm{ha}$, respectively, over that calculated under $80 \mathrm{~kg}$ nitrogen level (71.20). Different intercropping treatments applied in rainy season brought out significant variation in the number of grains per spike and 1000 

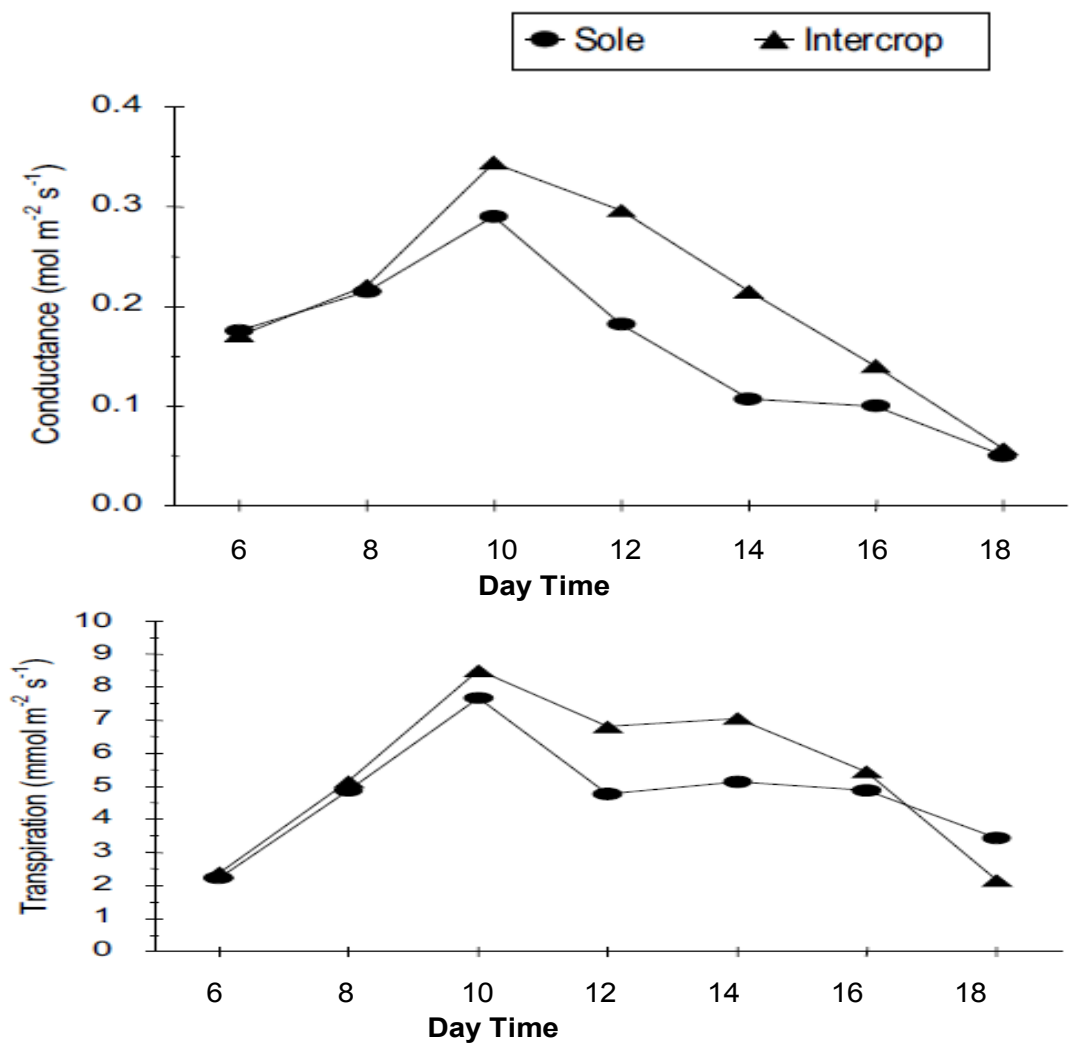

Figure 2. Diurnal fluctuation of stomatal conductance and transpiration of maize sole crop and intercropped with legume.

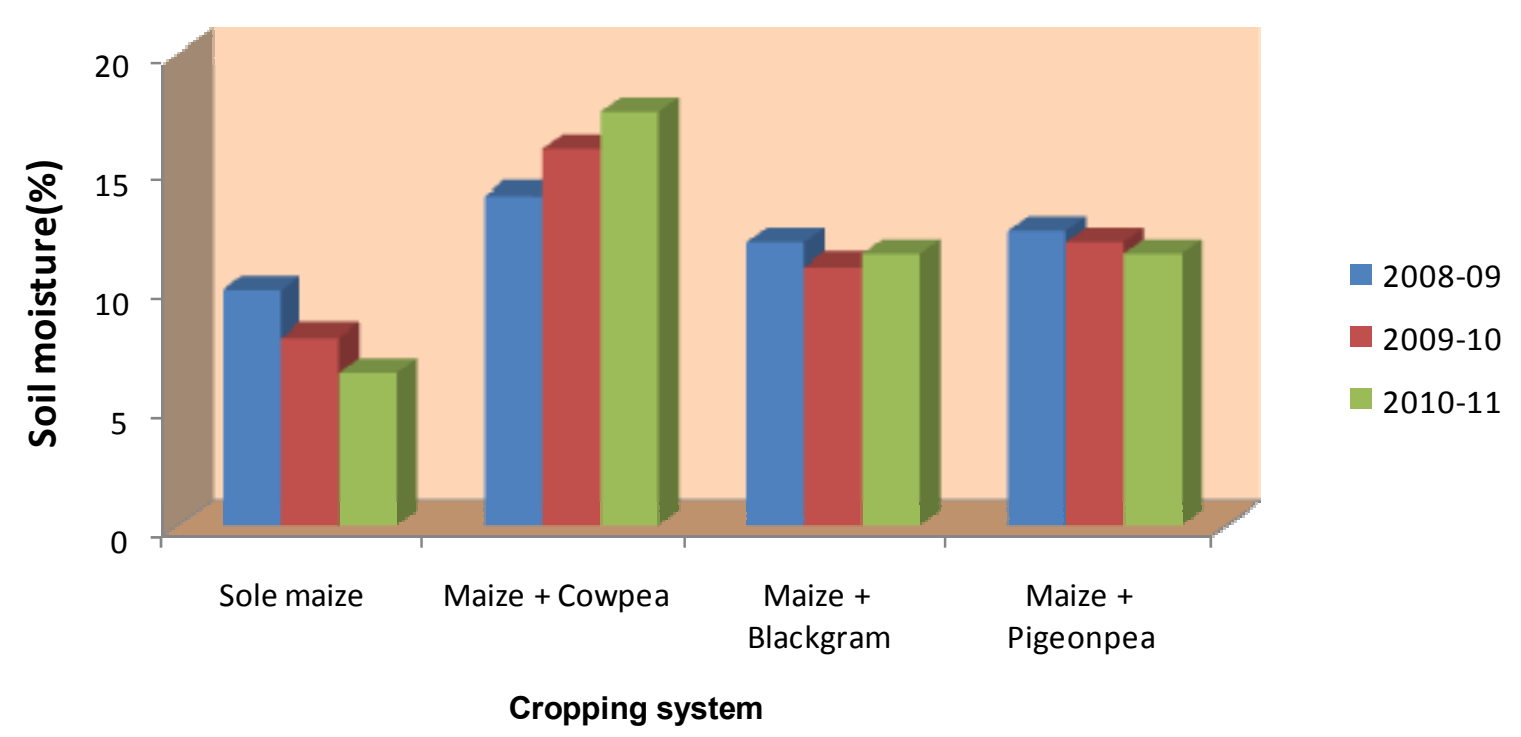

Figure 3. Variation of soil moisture (SM) at different cropping systems.

grain weight in wheat during the years of study.

The number of grains/spike and 1000-grain weight gradually reduced from 56.6 to 42.6 and 42.6 to $35.7 \mathrm{~g}$, respectively, during initial and final years of the study in the control plot where sole maize during rainy season was raised. While in the case of intercropping treatments, numbers of grains/spike and 1000 grain weight under different intercropping treatments were significantly 


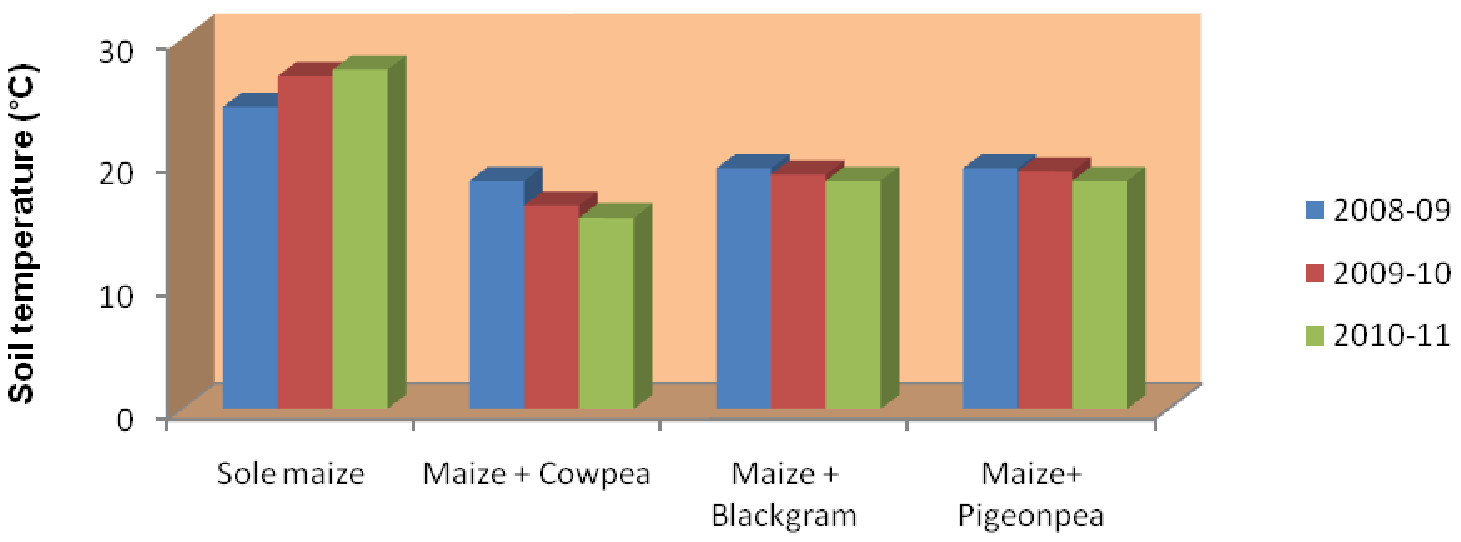

Cropping system

Figure 4. Variation of soil temperature (ST) at different cropping systems.

superior over the control plots but were at par during the third year of the study. Increasing level of nitrogen significantly increased the grains/spike and 1000 grain weight up to $120 \mathrm{~kg} \mathrm{~N} / \mathrm{ha}$. On mean basis, grains/spike increased by 30.8 and $34.0 \%$ at 120 and $160 \mathrm{~kg} \mathrm{~N} / \mathrm{ha}$, respectively, over that observed (35.7grains) under initial level of nitrogen. Similarly, 1000 grain weight were increased by 14.2 and $16.4 \%$ at 120 and $160 \mathrm{~kg} \mathrm{~N} / \mathrm{ha}$, when compared with those counted (36.2) at initial nitrogen level. These results were in close conformity with that of Solanki et al. (2011) and Undie et al. (2012).

\section{Yield and economic analysis}

Maize yield was significantly affected by different intercropping treatments, where pigeonpea intercropping in contrast to pure stand of maize reduced the maize yield significantly. However, the grain yield of subsequent wheat crop was significantly increased due to different intercropping treatments applied to maize. During the first year of the study, wheat yields obtained under the plots treated with FYM (40.35 q/ha) or intercropped with blackgram in 2:2 row ratios (39.64 q/ha) produced significantly superior yield as compared to the control plot $(37.82 \mathrm{q} / \mathrm{ha})$. During the following years, the control plot showed a gradual decline in wheat yield by 4.49 and $8.89 \%$, respectively, during $2009-10$ and $2010-11$. During these years, wheat yields obtained under the plots either treated with FYM or intercrops were significantly higher than that of yield obtained under the respective control plots. This increase in wheat yield might be attributed to nitrogen benefit to soil due to blackgram and cowpea intercropping. Wheat yield significantly increased up to $160 \mathrm{~kg} \mathrm{~N} / \mathrm{ha}$. However, there was no significant increase in yield of maize beyond $120 \mathrm{~kg} \mathrm{~N} /$ ha (Table 3). B : C ratio analysis indicated that the $B$ : $C$ ratio of 2.03 was calculated when maize in paired rows was intercropped with blackgram in 2:2 row ratios (30/90 cm wide beds), followed by wheat. Cowpea intercropping in a similar fashion was the next best treatment in sustaining productivity of wheat as compared to the control. These results are in conformity with the findings of Shah et al. (1991).

\section{Nutrient studies}

Organic carbon contents varied with different intercropping treatments (Table 3). After completion of the study, the control plot, having pure maize-wheat rotation, showed a decline in soil organic carbon of $3.70 \%$, while blackgram and cowpea inter-cropping with maize in paired rows in 2:2 row ratio followed by wheat increased content of organic carbon in soil as 0.63 and $0.67 \%$, respectively, as compared to initial values of $0.54 \%$. Total nitrogen content of soil also increased with increasing level of nitrogen (Table 4) in all the intercropping treatments. The highest total nitrogen $(1399 \mathrm{~kg} / \mathrm{ha})$ was found under maize + cowpea (paired rows in 2:2 row ratios $(30 / 90 \mathrm{~cm})$ ) wheat treatment with net positive $\mathrm{N}$ balance of $139 \mathrm{~kg} / \mathrm{ha}$ less than $160 \mathrm{~kg} \mathrm{~N} / \mathrm{ha}$ level. This increase in $\mathrm{N}$ availability might be due to the decaying of nodules in legumes. These results are in line with the findings of Saleem et al. (2011) and Naresh et al. (2011).

From the above, it can be concluded that there are opportunities for improving the productivity of maizewheat system with legumes intercropping in the western Uttar Pradesh, India. Intercropping is the best cropping system because in this system, light interception, soil moisture, soil temperature and yields were higher as compared to sole crops. Microclimatic variations in intercropping system had caused favourable environmental conditions for growth and high yield as compared to sole crops. The legume-maize intercropping exploited more soil moisture than a sole maize crop; the beneficial effects of the inter-cropping appeared to greatly compensate for the interception and uptake 
Table 1. Growth and yield attributing characters of maize as affected by legume intercropping and $\mathrm{N}$ levels.

\begin{tabular}{|c|c|c|c|c|c|c|c|c|c|c|c|c|}
\hline \multirow{3}{*}{ Intercropping treatments } & \multicolumn{12}{|c|}{ Growth and yield attributes } \\
\hline & \multicolumn{4}{|c|}{ Plant height $(\mathrm{cm})$ at harvest } & \multicolumn{4}{|c|}{ Dry matter at 90 DAS (g plant ${ }^{-1}$ ) } & \multicolumn{4}{|c|}{ Shelling (\%) } \\
\hline & 08-09 & 09-10 & $10-11$ & Mean & 08-09 & 09-10 & $10-11$ & Mean & 08-09 & 09-10 & $10-11$ & Mean \\
\hline $\mathrm{T}_{1}$ Sole maize (60 cm narrow beds)- wheat (control) & 260.7 & 258.3 & 269.8 & 262.9 & 120.7 & 116.4 & 123.6 & 120.2 & 74.1 & 73.9 & 72.3 & 73.4 \\
\hline $\mathrm{T}_{2}$ Sole maize (60 cm narrow beds with FYM @ 10t/ha-wheat & 277.9 & 271.2 & 276.3 & 275.1 & 132.7 & 128.9 & 136.2 & 132.6 & 71.8 & 72.9 & 73.6 & 72.8 \\
\hline $\begin{array}{l}\mathrm{T}_{3} \text { Maize }+ \text { blackgram paired row in } 2: 2 \text { row ratio }(30 / 90 \mathrm{~cm} \\
\text { wide beds)-wheat }\end{array}$ & 253.7 & 249.6 & 267.4 & 256.9 & 106.2 & 112.7 & 119.4 & 112.8 & 71.7 & 73.2 & 72.8 & 72.6 \\
\hline $\begin{array}{l}T_{4} \text { Maize + cowpea paired row in } 2: 2 \text { row ratio }(30 / 90 \mathrm{~cm} \text { wide } \\
\text { beds) -wheat }\end{array}$ & 251.6 & 257.9 & 258.3 & 255.9 & 98.7 & 114.3 & 121.6 & 111.5 & 73.1 & 72.6 & 72.9 & 72.9 \\
\hline $\begin{array}{l}T_{5} \text { Maize + pigeonpea alternate rows in } 1: 1 \text { row ratio }(30 / 30 \mathrm{~cm} \\
\text { flat beds ) - wheat }\end{array}$ & 248.7 & 253.5 & 256.7 & 253.0 & 118.5 & 123.4 & 126.8 & 122.9 & 72.3 & 71.8 & 72.6 & 72.2 \\
\hline $\begin{array}{l}\mathrm{T}_{6} \text { Maize + blackgram alternate rows in } 1: 1 \text { row ratio }(30 / 30 \mathrm{~cm} \\
\text { flat beds ) - wheat }\end{array}$ & 242.2 & 251.8 & 257.6 & 250.5 & 92.3 & 109.6 & 117.9 & 106.6 & 71.3 & 72.6 & 72.3 & 72.1 \\
\hline C D at $5 \%$ & 6.8 & 9.3 & 8.6 & - & 3.2 & 5.8 & 4.7 & - & NS & NS & NS & - \\
\hline \multicolumn{13}{|l|}{ Nitrogen levels (kg/ha) } \\
\hline 80 & 229.7 & 240.3 & 249.2 & 239.7 & 95.2 & 103.5 & 108.4 & 102.4 & 71.2 & 71.5 & 70.8 & 71.2 \\
\hline 120 & 254.1 & 265.4 & 267.9 & 262.5 & 109.3 & 123.4 & 127.7 & 120.1 & 72.3 & 73.4 & 72.8 & 72.8 \\
\hline 160 & 267.3 & 274.1 & 271.6 & 271.0 & 112.6 & 128.6 & 131.5 & 124.2 & 72.4 & 73.7 & 73.2 & 73.1 \\
\hline C D at $5 \%$ & 3.4 & 4.09 & 2.41 & - & 3.6 & 6.11 & 3.84 & - & 0.73 & 0.69 & 0.58 & - \\
\hline
\end{tabular}

Table 2. Yield attributing characters of wheat as affected by legume intercropping and $\mathrm{N}$ level.

\begin{tabular}{|c|c|c|c|c|c|c|c|c|c|c|c|c|}
\hline \multirow{3}{*}{ Intercropping treatments } & \multicolumn{12}{|c|}{ Yield attributes } \\
\hline & \multicolumn{4}{|c|}{ Spikelets spike $^{-1}$} & \multicolumn{4}{|c|}{ Number of grains spike $^{-1}$} & \multicolumn{4}{|c|}{ 1000- Grain weight in (g) } \\
\hline & 08-09 & $09-10$ & $10-11$ & Mean & 08-09 & 09-10 & $10-11$ & Mean & 08-09 & 09-10 & $10-11$ & Mean \\
\hline $\mathrm{T}_{1}$ Sole maize (60cm narrow beds)- wheat (control) & 11.7 & 11.4 & 12.3 & 11.8 & 42.6 & 43.9 & 44.6 & 43.7 & 35.7 & 36.6 & 37.8 & 36.7 \\
\hline $\mathrm{T}_{2}$ Sole maize $(60 \mathrm{~cm}$ narrow beds with FYM @ 10t/ha-wheat & 12.8 & 12.1 & 13.6 & 12.8 & 44.7 & 45.3 & 45.8 & 45.3 & 36.1 & 38.3 & 36.7 & 37.0 \\
\hline $\begin{array}{l}T_{3} \text { Maize+blackgram paired row in 2:2 row ratio }(30 / 90 \mathrm{~cm} \\
\text { wide beds )-wheat }\end{array}$ & 14.3 & 14.7 & 15.6 & 14.9 & 52.6 & 53.1 & 55.3 & 53.7 & 41.3 & 42.7 & 42.4 & 42.1 \\
\hline $\begin{array}{l}T_{4} \text { Maize + cowpea paired row in } 2: 2 \text { row ratio }(30 / 90 \mathrm{~cm} \text { wide } \\
\text { beds )-wheat }\end{array}$ & 14.8 & 15.3 & 16.4 & 15.5 & 53.8 & 54.1 & 56.6 & 54.8 & 42.7 & 41.9 & 42.6 & 42.4 \\
\hline $\begin{array}{l}\mathrm{T}_{5} \text { Maize + pigeonpea alternate rows in } 1: 1 \text { row ratio }(30 / 30 \mathrm{~cm} \\
\text { flat beds ) - wheat }\end{array}$ & 13.2 & 13.8 & 14.6 & 13.9 & 48.7 & 51.0 & 53.4 & 51.0 & 41.3 & 41.6 & 42.4 & 41.8 \\
\hline
\end{tabular}


Table 2. Contd.

\begin{tabular}{|c|c|c|c|c|c|c|c|c|c|c|c|c|}
\hline $\begin{array}{l}\mathrm{T}_{6} \text { Maize +blackgram alternate rows in } 1: 1 \text { row ratio }(30 / 30 \mathrm{~cm} \\
\text { flat beds ) - wheat }\end{array}$ & 11.9 & 12.3 & 12.8 & 12.3 & 48.5 & 49.0 & 52.5 & 50.0 & 39.5 & 40.8 & 41.3 & 40.5 \\
\hline C D at $5 \%$ & 1.08 & 1.27 & 0.93 & - & 4.06 & 6.59 & 4.35 & - & 0.94 & 1.29 & 1.65 & - \\
\hline \multicolumn{13}{|l|}{ Nitrogen levels (kg/ha) } \\
\hline 80 & 11.1 & 13.3 & 13.2 & 12.5 & 31.3 & 36.2 & 39.7 & 35.7 & 35.3 & 36.8 & 36.4 & 36.2 \\
\hline 120 & 13.4 & 14.7 & 15.5 & 14.5 & 50.6 & 51.5 & 52.8 & 51.6 & 41.3 & 42.5 & 42.8 & 42.2 \\
\hline 160 & 14.8 & 15.2 & 16.4 & 15.5 & 52.7 & 53.4 & 56.3 & 54.1 & 42.9 & 43.2 & 43.7 & 43.3 \\
\hline C D at $5 \%$ & 1.54 & 0.65 & 0.97 & - & 2.61 & 2.11 & 3.84 & - & 2.06 & 1.52 & 1.44 & - \\
\hline
\end{tabular}

Table 3. Grain yield and net monetary returns, and soil organic carbon of maize-wheat cropping system as affected by legume intercropping and $\mathrm{N}$ levels.

\begin{tabular}{|c|c|c|c|c|c|c|c|c|c|c|}
\hline \multirow{3}{*}{ Intercropping treatments } & \multicolumn{8}{|c|}{ Grain yield (q/ha ) } & \multirow{3}{*}{$\begin{array}{l}\mathrm{B}: \mathrm{C} \\
\text { ratio }\end{array}$} & \multirow{3}{*}{$\begin{array}{l}\text { O.C. } \\
(\%)\end{array}$} \\
\hline & \multicolumn{4}{|c|}{ Maize and intercrops } & \multicolumn{4}{|c|}{ Wheat } & & \\
\hline & 08-09 & $09-10$ & $10-11$ & Mean & $08-09$ & $09-10$ & $10-11$ & Mean & & \\
\hline $\mathrm{T}_{1}$ Sole maize (60cm narrow beds)-wheat (control) & 39.13 & 40.05 & 40.95 & 40.04 & 37.82 & 36.12 & 34.46 & 36.13 & 1.92 & 0.52 \\
\hline $\begin{array}{l}T_{2} \text { Sole maize }(60 \mathrm{~cm} \text { narrow beds with FYM @ } \\
10 \mathrm{t} / \text { ha-wheat }\end{array}$ & 42.60 & 43.45 & 45.60 & 43.88 & 40.35 & 40.19 & 41.40 & 40.65 & 1.87 & 0.58 \\
\hline $\begin{array}{l}T_{3} \text { Maize+blackgram paired row in } 2: 2 \text { row ratio } \\
(30 / 90 \mathrm{~cm} \text { wide beds )-wheat }\end{array}$ & $41.85(2.85)^{*}$ & $42.75(3.85)^{*}$ & $43.15(4.45)^{*}$ & $42.58(3.72)$ & 39.64 & 38.00 & 37.90 & 38.51 & 2.03 & 0.63 \\
\hline $\begin{array}{l}\mathrm{T}_{4} \text { Maize+ cowpea paired row in } 2: 2 \text { row ratio } \\
(30 / 90 \mathrm{~cm} \text { wide beds )-wheat }\end{array}$ & $40.42(3.65)^{*}$ & $41.40(4.35)^{*}$ & $42.65(5.25)^{*}$ & $41.49(4.42)$ & 37.95 & 39.10 & 38.35 & 38.47 & 2.01 & 0.67 \\
\hline $\begin{array}{l}T_{5} \text { Maize }+ \text { pigeonpea alternate rows in } 1: 1 \text { row } \\
\text { ratio }(30 / 30 \mathrm{~cm} \text { flat beds }) \text { - wheat }\end{array}$ & $34.50(3.24)^{*}$ & $36.65(4.45)^{*}$ & $37.60(5.80)^{*}$ & $36.25(4.49)$ & 38.45 & 38.30 & 37.75 & 38.17 & 1.98 & 0.51 \\
\hline $\begin{array}{l}T_{6} \text { Maize }+ \text { blackgram alternate rows in } 1: 1 \text { row } \\
\text { ratio }(30 / 30 \mathrm{~cm} \text { flat beds }) \text { - wheat }\end{array}$ & $38.46(2.82)^{*}$ & $39.35(3.75)^{*}$ & $40.85(5.65)^{*}$ & $39.55(4.07)$ & 39.40 & 38.30 & 37.20 & 38.30 & 1.96 & 0.61 \\
\hline C D at $5 \%$ & 2.54 & 2.08 & 3.15 & - & 1.92 & 2.16 & 2.35 & - & - & 0.049 \\
\hline \multicolumn{11}{|l|}{ Nitrogen levels (kg/ha) } \\
\hline 80 & $24.60(2.60)$ & $27.35(2.95)$ & $28.20(3.15)$ & $26.72(2.90)$ & 28.25 & 35.20 & 32.15 & 31.87 & 1.83 & 0.56 \\
\hline 120 & $40.35(3.85)$ & $41.85(4.25)$ & $42.45(4.85)$ & $41.55(4.32)$ & 42.80 & 38.95 & 39.85 & 40.53 & 1.99 & 0.59 \\
\hline 160 & $41.35(3.60)$ & $42.80(4.45)$ & $43.75(4.95)$ & $42.63(4.33)$ & 45.80 & 41.15 & 41.65 & 42.87 & 2.08 & 0.61 \\
\hline C D at $5 \%$ & 1.65 & 2.82 & 3.73 & - & 2.14 & 2.32 & 2.23 & - & - & $\begin{array}{l}\text { N.S. } \\
0.54^{* *}\end{array}$ \\
\hline
\end{tabular}

${ }^{*}$ Figure in parentheses indicate yield of intercrops, " Initial value. 
Table 4. Balance sheet of total nitrogen in maize + intercrops-wheat cropping system $(\mathrm{kg} / \mathrm{ha})$.

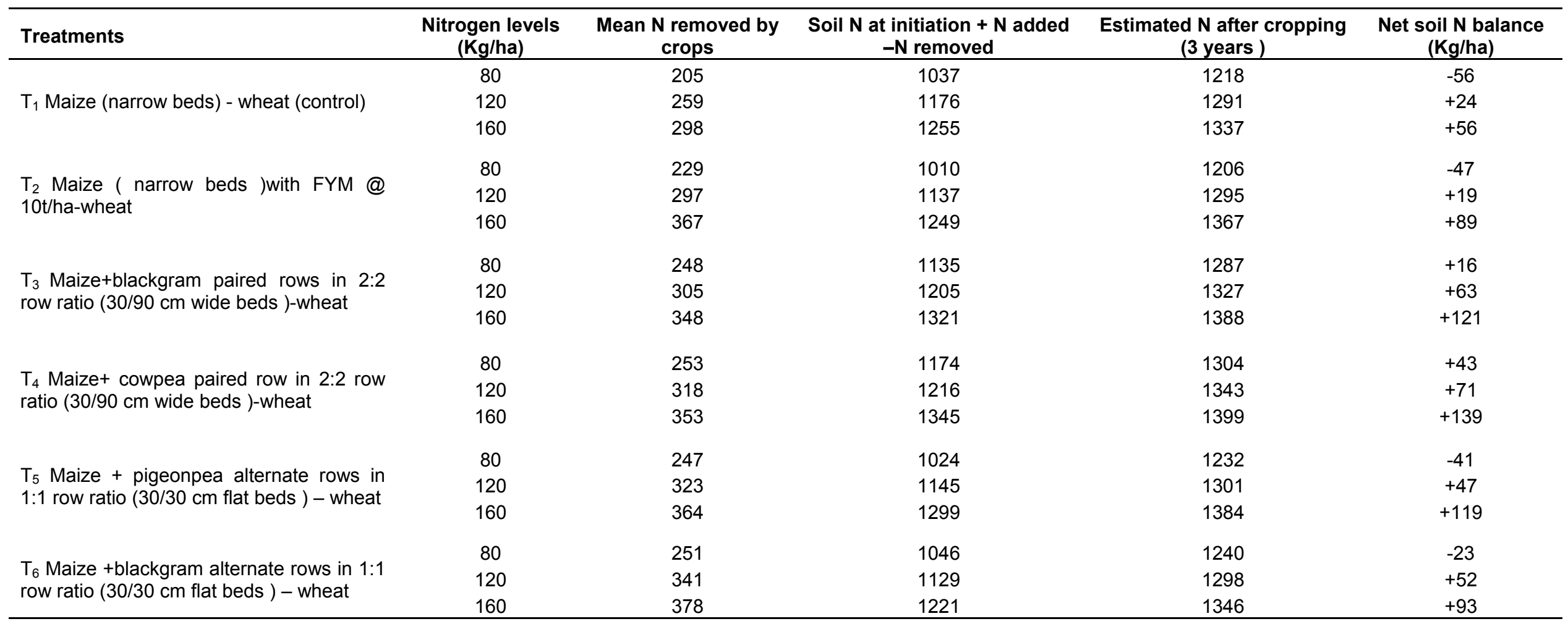

losses near the legume crops canopy. Intercropping improves water relations as compared to the sole crops and intercropped maize is more competitive than cowpea in terms of use of resource uptake, mainly soil moisture. In intercropping system, water uptake from soil surface layers increased due to increased root density in the upper layers, thus decreasing water dissipated by evaporation. However, it is evident from the results that legumes and legume-maize intercropping are more effective in improving soil moisture and decrease evaporation from the soil surface due to shading and increase the soil moisture potentially available for transpiration and growth as compared to sole maize.

A yield advantage in intercropping is achieved only when components crops do not compete for the same resources over the same time and space. In these experiments, the degree of below ground competition was not determined, so it is only possible to comment on above ground competition, showing that the sharing of light by the component crops was important for better utilization of resources, resulting in higher productivity of the intercropping system. The maize canopy alone could not utilize all incoming radiation during the growing period, and the remaining solar radiation was captured by the legumes when grown under maize, showing complementarity in use of resources. Maize + blackgram paired row in $2: 2$ row ratio $(30 / 90 \mathrm{~cm}$ wide beds) followed by wheat having a $\mathrm{B}: \mathrm{C}$ ratio of 2.03 had increased contents of organic carbon in soil as $0.63 \%$ as compared to initial values of $0.54 \%$. Nitrogen balance under different intercropping treatments was better. The buildup of soil $\mathrm{N}(121 \mathrm{~kg} \mathrm{~N} / \mathrm{ha}$ ) was observed under this intercropping. Thus, blackgram intercropping with maize in paired rows in $2: 2$ row ratios $(30 / 90 \mathrm{~cm}$ 
wide beds) followed by wheat was found to be the most sustainable for semi-arid region of western Uttar Pradesh, India.

\section{ACKNOWLEDGEMENTS}

The authors are grateful to the Director Research of the Sardar Vallabhbhai Patel University of Agriculture and Technology, Meerut U.P., India for providing facilities and encouragement. The financial support received from the Uttar Pradesh council of Agricultural Research, Lucknow during the course of the study is gratefully acknowledged.

\section{REFERENCES}

Anil L, Park RH, Pand Miller FA (1998). Temperate intercropping of cereals for forage: A review of the potential for growth and utilization with particular reference to the UK. Grass Forage Sci. 53:301-317.

Dhima KV, Lithourgidis AA, Vasilakoglou IB, Dordas CA (2007). Competition indices of common vetch and cereal intercrops in two seeding ratio. Field Crops Res. 100:249-256.

Donald CM (1985). The interaction of competition for light and for nutrients. Aust. J. Agric. Res. 9:421-435.

Ghanbari A, Dahmardeh M, Siahsar BA, Ramroudi M (2010). Effect of Maize (Zea mays L.) - Cowpea (Vigna unguiculata L.) Intercropping on Light Distribution, Soil Temperature and Soil Moisture in Arid Environment. J. Food Agric. Environ. 8(1):102-108.

Hauggaard-Nielsen H, Andersen MK, Jørnsgaard B, Jensen ES (2006). Competitive dynamics in two- and three-component intercrops. Field Crops Res. 95:256-267.

Li L, Yang SC, Li XL, Zhang FS, Christie P (1999). Interspecific complementary and competitive interaction between intercropped maize and faba bean. Plant Soil 212:105-114.

Montgomery DR (2007). Soil erosion and agricultural sustainability. PNAS 104:13268-13272.
Naresh RK, Gupta RK, Singh B, Kumar A, Singh A, Gaurav SS, Singh M, Shahi UP, Ghyanshyam K (2011). Enhancing farmers' income and livelihoods through integrated crop and resource management in the crop diversification in North India. J. Sci. Appl. Res. 2(1):1-19.

Saleem R, Ahmed ZI, Ashraf M, Arif M, Malik MA, Munir M, Khan MA (2011). Response of Maize-Legume Intercropping System to Different Fertility Sources under Rainfed conditions.Sarhad J. Agric. 27(4):503-511.

Shah MH, Koul PK, Khanday BA, Kachroo D (1991). Production potential and monitetary advantage index of maize intercropped with different grain legumes. Indian J. Agron. 36:23-28.

Shackle KA, Hall AE (1984). Effect of intercropping on the water relations of sorghum and cowpea. Field Crops Res. 8:381-387.

Solanki NS, Singh D, Sumeriya HK (2011). Resources Utilization in Maize (Zea mays)-based Inter-cropping System under Rainfed Condition. Indian J. Agric. Sci. 81(6):511-515.

Swaminathan MS (1998). Crop production and sustainable food security. In Chopra, V. L., Singh, R. B. and Verma, A. (eds). Crop Productivity and Sustainability-Shaping the Future. Proceedings of the Second International Crop Science Congress, New Delhi, India, pp. 3-18.

Thomsen A (1994). Program AUTOTDR for making automated TDR measurements of soil water content. Users Guide, Version 01. Report 38. Danish Institute of Plant and Soil Science, Tjele, 29p.

Undie UL, Uwah DF, Attoe EE (2012). Growth and Development of Late Season Maize/Soybean Intercropping in Response to Nitrogen and Crop Arrangement in the Forest Agro-ecology of South Southern Nigeria. Int. J. Agric. Res. 7(1):1-16.

Willey RW (1979). Intercropping - Its importance and research needs.Part 1. Competition and yield advantages. Field Crops Abstr. 32:1-10.

Zhu Y, Chen H, Fan J, Wang Y, Li Y, Chen J, Fan J, Yang S, Hu L, Leung H, Mew TW, Teng PS, Wang Z, Mundt CC (2000). Genetic diversity and disease control in rice. Nat. 406:718-722. 